\title{
Restrictions and Methodologies for Distributed Sensor Network Security using Sensor Node Technology
}

\author{
V. Khanaa, S. Thirunavukkarasu, A. Rama
}

\begin{abstract}
Dissipated sensor outlines (DSNs) impact the amazing filtering of edge information utilizing a wide assortment of physical sensors (for example acoustic, seismic, visual) through a uniquely named remote framework affiliation. Advances in little scale electromechanical frameworks (MEMS) improvement empower instruments to be reprogrammable in the field of battle, self-obligatory and low-basic, remote, multi-impact the board while, simultaneously, requiring on a very basic level unimportant pre-plan. So as to strengthen dependably the molded controller, affiliation and broadcasting fringes, the device frameworks will productively deal with both the decentralized control and the self-ruling direct sensor. Sensor gatherings will be little, lightweight, expert and low-control. Gone in sporadic diagrams over the finished remote and as every now and again as possible undermining conditions, will the sensor center around self-choice mean agreeable, dissipated developments? Sensor structures should be effective and enduring, paying little character to the novel focal point of disappointment and sporadic system. High data verification will be furnished with little regard to the utilization of unattended sensor bunches with reasonably touchy impenetrability to adjustment.
\end{abstract}

Keywords: Hardware Design, Sensor framework

\section{INTRODUCTION}

Sensor framework correspondences must maintain a strategic distance from introduction and undetected difference in exchanged messages. Giving protection and request is fundamental to protecting a foe from exchanging off the security of a scattered sensor structure. Notwithstanding, giving key relationship to security and social event level underwriting is inconvenient in context on the without any planning nature, broken receptiveness, and resource confinements of the dissipated sensor structure condition. Our assessment revolves around one and just security issue in this security space: Key relationship for social occasion and pressing level endorsement in Asset Restricted Streamed Sensor Structures This survey doesn't address physical wellbeing of the Sensor Focus, enticing figuring for performing mystery information and message proclamation, or primary relationship for other Sensor Focus Limits, for example nonstop bouncing and spread of degree trades and Global Positioning Sy. [1-5].

Focuses are arrangements that are clearly created to relieve

Revised Manuscript Received on August 22, 2019.

V. Khanaa, Department of Information Technology, Bharath Institute of Higher Education and Research, Chennai, Tamilnadu, India.

S. Thirunavukkarasu, Department of Information Technology, Bharath Institute of Higher Education and Research, Chennai, Tamilnadu, India.

A. Rama, Department of Information Technology, Bharath Institute of Higher Education and Research, Chennai, Tamilnadu, India. activity and to be inconsequential effort, reduced, lightweight and immaterial. Neighboring and bunch flag Prepare the refresh sensor concentrate over the distant structure focuses on crude, unique containment points (e.g., seismic, acoustic, charming). Running with pieces depicts parts of these mid-points that sponsor key sections of the focus sensor, including: occasional area, opportunity or target approach, post-target targeting, and occasion detailing [6-9].

Hardware Design Recognizing the ultimate goal of improving strategy and enhancing casual system development, we expect the future focus of the sensor to reinforce the structuring of flexible equipment and programming aids that will enable them to cope with different components of the framework (e.g. gateway rather than focus recognition).

Support the association of low-central structures to trade data locally over a distant multi-chip phenomenological named structure; $\bullet$ Support the entire course of action trading data over whole game plan radio circuits (for instance definitely when picked as a segment focus) 2 Communications Architecture Sensor focus may be pulverized for conflicting access to the strategy. Right when the game-plan is passed on, automatic, developing a controlling topology that gives solid straightforwardness all through the structure (i.e., a course exists between each inside point). This system will genuinely remove obliged focus fixations from the structure [7-12].

\section{Methodologies}

A sensor center may experience a motion of phases beginning with its generation and inducing its connection in a sensor structure over a lengthy period of time. Going to the Territories depicts a non-explicit idea of duties that might be connected with sensor center points and sensor frameworks. It is expected that a typical operational situation may be combined with steps, each of which is delineated with parts: generation of sensor center points, temporary terminal limit of sensors, presentation of transmitting sensors, combination of sensor center points, mission assignments, and mission satisfaction.

Manufacturing During the amassing operation, the center equipment of the sensor is collected and the focus is written. - The forwarding method probably won't have the chance to regulate frameworks that allow unauthorized hardware or programming modifications; Software bugs may approve of the primate screw up in the

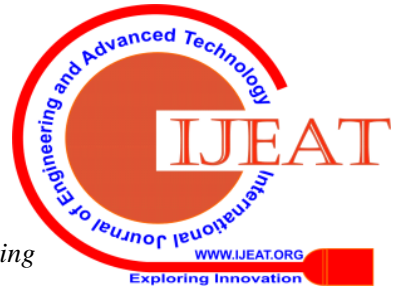


purpose of union of the improvement system.

In setting on by a wide edge the vast majority of the estimations of the sensor center centers that could be given, we see that the amassing structure won't be properly controlled. In any case, this additional security adds to the cost of each sensor and is contrary to the objective of being useful and consumable [13-16].

\section{A. Pre-Deployment}

All together, it may be critical to instate or pre-structure the centers for the sensor centers to be sent within the sensor context. Irrespective of that, we trust that a certain percentage of the pre-course of action will always be critical to the perception of real blue sensor centers. Distinctive frameworks Unequivocal frameworks may be used to lessen the technique and, in that limit, the basic for physical security. Cryptographic structures, for instance, rule bit or essential sharing, may diminish the match plan for the genuine substance. Change the safety and recognition frameworks may be used in the same way [17-20].

\section{RESULT AND DISCUSSION}

Time Varying Approaches despite contrasting methodologies for areas within the framework, important organizational methods may alter in the same way most far off point may be kept up identically in the going with events of the sensor structure's lifetime. may "practice" in express parts. Since all sensors can perform seeing, trades, and security limits, it may It is useful for the entire sensor structure to have a couple of sensors perform could be continuously exchanged after some time. Or maybe a successful move to increasingly granular keys is encouraged. Thus, in addition, since the sensor center points use the battery essentials after some moment, trading off safety for impermanence capacity may be advocated in comparable way after some time. Structure wide pre-sent keys could be used to help the establishment of starting keying relationship, in any case using such keys all through the lifetime of the focal reason sensor, perils could be unendingly exchanged after some time the most distinguishing function, others center on correspondence, and still others center on safety boundaries. Particularly in the case of a key organization, a sensor center point can self-handle a vitality wasteful part of a key assignment center or a Rich Uncle, in addition to its including sensor center points, by using a great deal of safety imperative [21-30].

\section{CONCLUSION}

Regardless of the way that our examination has perceived key organization essentialness efficiency improvements for different circumstances, further changes are possible. We have recognized the going with regions was additional exploration would overhaul key organization execution:

- Development of an upgraded assembling assurance computation - The figuring we are starting at now using is flawed since it just finds the greatest social affair available, however a tinier get-together may give a progressively imperative abatement in essentialness usage depending upon the general places of the get-together people.

\section{REFERENCES}

[1] Gowri Sankaran, B., Karthik, B. \& Vijayaragavan, S.P. 2019, "Weight ward change region plummeting change for square based image huffman coding", International Journal of Innovative Technology and Exploring Engineering, vol. 8, no. 10, pp. 4313-4316.

[2] Gowri Sankaran, B., Karthik, B. \& Vijayaragavan, S.P. 2019, "Image compression utilizing wavelet transform", International Journal of Innovative Technology and Exploring Engineering, vol. 8, no. 10, pp. 4305-4308.

[3] Kandavel, N. \& Kumaravel, A. 2019, "Offloading computation for efficient energy in mobile cloud computing", International Journal of Innovative Technology and Exploring Engineering, vol. 8, no. 10, pp. 4317-4320.

[4] Vinoth, V.V. \& Kanniga, E. 2019, "Reversible data hiding in encrypting images-an system", International Journal of Engineering and Advanced Technology, vol. 8, no. 6, pp. 3051-3053.

[5] Selvapriya, B. \& Raghu, B. 2019, "Pseudocoloring of medical images: A research", International Journal of Engineering and Advanced Technology, vol. 8, no. 6, pp. 3712-3716.

[6] Senthil Kumar, K. \& Muthukumaravel, A. 2019, "Bi-objective constraint and hybrid optimizer for the test case prioritization", International Journal of Engineering and Advanced Technology, vol. 8, no. 6, pp. 3436-3448.

[7] Kavitha, G., Priya, N., Anuradha, C. \& Pothumani, S. 2019 , "Read-write, peer-to-peer algorithms for the location-identity split", International Journal of Innovative Technology and Exploring Engineering, vol. 8, no. 9 Special Issue 3, pp. 445-447.

[8] Kaliyamurthie, K.P., Michael, G., Anuratha, C. \& Sundaraj, B. 2019, "Certain improvements in alzheimer disease classification using novel fuzzy c means clustering for image segmentation", International Journal of Innovative Technology and Exploring Engineering, vol. 8, no. 9 Special Issue 3, pp. 599-604.

[9] Kaliyamurthie, K.P., Sundarraj, B., Geo, A.V.A. \& Michael, G. 2019 , "RIB: Analysis of I/O automata", International Journal of Innovative Technology and Exploring Engineering, vol. 8, no. 9 Special Issue 3, pp. 1019-1022.

[10] Velvizhi, R., Rajabhushanam, C. \& Vidhya, S.R.S. 2019, "Opinion mining for travel route recommendation using Social Media Networks (Twitter)", International Journal of Innovative Technology and Exploring Engineering, vol. 8, no. 9 Special Issue 3, pp. 508-512.

[11] Kavitha, R., Sangeetha, S. \& Varghese, A.G. 2019, "Human activity patterns in big data for healthcare applications", International Journal of Innovative Technology and Exploring Engineering, vol. 8, no. 9 Special Issue 3, pp. 1101-1103.

[12] Pothumani, S., Anandam, A.K., Sharma, N. \& Franklin, S. 2019, "Extended VEOT framework - Implemented in a smart boutique", International Journal of Innovative Technology and Exploring Engineering, vol. 8, no. 9 Special Issue 3, pp. 762-767.

[13] Kaliyamurthie, K.P., Michael, G., Krishnan, R.M.V. \& Sundarraj, B. 2019, "Pseudorandom techniques for the internet", International Journal of Innovative Technology and Exploring Engineering, vol. 8, no. 9 Special Issue 3, pp. 915-918.

[14] Aravindasamy, R., Jeffrin Rajan, M., Rama, A. \& Kavitha, P. 2019, "Deep learning provisions in the matlab: Focus on CNN facility", International Journal of Innovative Technology and Exploring Engineering, vol. 8, no. 9 Special Issue 3, pp. 990-994.

[15] Theivasigamani, S., Linda, M. \& Amudha, S. 2019, "Object sensing and its identification \& motion sensing", International Journal of Innovative Technology and Exploring Engineering, vol. 8, no. 9 Special Issue 3, pp. 545-549.

[16] Mary Linda, I., Vimala, D. \& Shanmuga Priya, K. 2019, "A methodology for the emulation of IPv4", International Journal of Innovative Technology and Exploring Engineering, vol. 8, no. 9 Special Issue 3, pp. 848-852.

[17] Velvizhi, R., Priya, D.J., Vimala, D. \& Linda, I.M. 2019, "Increased routing algorithm for mobile adhoc networks", International Journal of Innovative Technology and Exploring Engineering, vol. 8, no. 9 Special Issue 3, pp. 1606-1608

[18] Sangeetha, S., Anuradha, C. \& Priya, N. 2019, "DNS in real world", International Journal of Innovative Technology and Exploring Engineering, vol. 8, no. 9 Special Issue 3, pp. 937-940.

[19] Geetha, C., Vimala, D. \& Priya, K.S. 2019, "Constructing multi-processors and spreadsheets with SKIVE", International Journal of Innovative Technology and Exploring Engineering, vol. 8, no. 9 Special Issue 3, pp. 516-519.

[20] Yugendhar, K., Sugumar, V. \& Kavitha, P. 2019, "A novel method 
of univac using fuzzy logic", International Journal of Innovative Technology and Exploring Engineering, vol. 8, no. 9 Special Issue 3, pp. 435-437.

[21] Kaliyamurthie, K.P., Michael, G., Elankavi, R. \& Jijo, S.A. 2019, "Implementing aggregate-key for sharing data in cloud environment using cryptographic encryption", International Journal of Innovative Technology and Exploring Engineering, vol. 8, no. 9 Special Issue 3, pp. 957-959.

[22] Jeffrin Rajan, M., Aravindasamy, R., Kavitha, P. \& Rama, A. 2019, "A novel method of object orientation variation in $\mathrm{C}++$ and java", International Journal of Innovative Technology and Exploring Engineering, vol. 8, no. 9 Special Issue 3, pp. 708-710.

[23] Nayak, R., Dinesh, S. \& Thirunavukkarasu, S. 2019, "A novel method improvement of rapid miner for the data mining applications", International Journal of Innovative Technology and Exploring Engineering, vol. 8, no. 9 Special Issue 3, pp. 457-460.

[24] Sivaraman, K., Krishnan, R.M.V., Sundarraj, B. \& Sri Gowthem, S. 2019, "Network failure detection and diagnosis by analyzing syslog and SNS data: Applying big data analysis to network operations", International Journal of Innovative Technology and Exploring Engineering, vol. 8, no. 9 Special Issue 3, pp. 883-887.

[25] Vimala, D., Linda, I.M. \& Priya, K.S. 2019, "Decoupling online algorithms from erasure coding in DNS", International Journal of Innovative Technology and Exploring Engineering, vol. 8, no. 9 Special Issue 3, pp. 950-953.

[26] Rama, A., Kumaravel, A. \& Nalini, C. 2019, "Preprocessing medical images for classification using deep learning techniques", International Journal of Innovative Technology and Exploring Engineering, vol. 8 , no. 9 Special Issue 3, pp. 711-716.

[27] Sangeetha, S., Srividhya, S.R., Anita Davamani, K. \& Amudha, S. 2019, "A procedure for avoid overrun error in universal synchronous asynchronous receiver transmitter (usart) by utilizing dummy join and interrupt latency method", International Journal of Innovative Technology and Exploring Engineering, vol. 8, no. 9 Special Issue 3, pp. 657-660.

[28] Aravindasamy, R., Jeyapriya, D., Sundarajan, B. \& Sangeetha, S. 2019, "Data duplication in cloud for optimal performance and security", International Journal of Innovative Technology and Exploring Engineering, vol. 8, no. 9 Special Issue 3, pp. 1156-1158.

[29] Aravindasamy, R., Jeffrin Rajan, M., Sugumar, V. \& Kavitha, P. 2019, "A novel method on developing superblocks and the transistor using apodryal", International Journal of Innovative Technology and Exploring Engineering, vol. 8, no. 9 Special Issue 3, pp. 982-985.

[30] Sasikumar, C.S. \& Kumaravel, A. 2019, "E-learning attributes selection through rough set theory and data mining", International Journal of Innovative Technology and Exploring Engineering, vol. 8, no. 10 , pp. $3920-3924$.

\section{AUTHORS PROFILE}

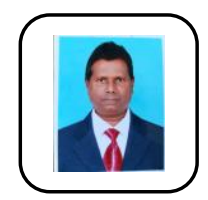

V. Khanaa, Professor, Department of Information Technology, Bharath Institute of Higher Education and Research, Chennai, India

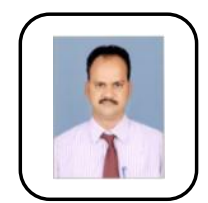

S. Thirunavukkarasu Assistant Professor, Department of Information Technology, Bharath Institute of Higher Education and Research, Chennai, India

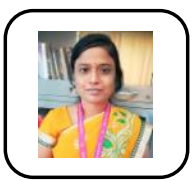

A. Rama Assistant Professor, Department of Information Technology, Bharath Institute of Higher Education and Research, Chennai, India 